\title{
The role of gamification exercises created with the help of the Hot Potatoes program in the formation of ship engineers' communicative competence
}

\section{Роль гейміфрікованих вправ, створених за програмою Hot Potatoes, у формуванні комунікативної компетентності суднових механіків}

\author{
Alona Yurzhenko, \\ Альона Юрженко, \\ Specialist of the Second Category, \\ Teacher \\ https://orcid.org/0000-0002-6560-4601 \\ спеціаліст другої категорії, \\ викладач \\ helen18@online.ua \\ Maritime college of Kherson State \\ Maritime Academy \\ $\triangle 20$ Ushakova st., \\ Kherson, 73000
Морський коледж Херсоснької державної морської академії $\triangle$ вул. Ушакова, 20, \\ м. Херсон, 73000

\section{Original manuscript received January 30, 2019 \\ Revised manuscript accepted April 04, 2019}

\begin{abstract}
Our research deals with the use of innovation technologies in the professional training of future marine specialists, namely ship engineers. As the title implies the article describes the role of gamification activities (educational exercises in the form of a game) created with the help of the Hot Potatoes program and placed in LMS MOODLE (Learning management system Modular Object-Oriented Dynamic Learning Environment). Couple of "gamification activities" definitions are listed. The advantages of gamification activities while studying English for specific purpose are mentioned (diversify of the routine implementation of typical exercises in the educational and communicative electronic environment, increasing of motivation, prolonged term of interest in solving the problem and increasing of the probability of achieving the studying goal). The types of Hot Potatoes program gamification activities (JClose, JMatch, JQuiz, JCross, JMix, The Masher) are described. Their application in electronic courses in LMS MOODLE to study Maritime English for professional purpose is described. The elements of gamification of every created with the help of Hot Potatoes program activity are listed (points and marks, the possibility of using hints and clues, visual progress, the right to mistake, the opportunity to start the game again, game design - the presence of special buttons). It is highlighted that JClose allows teachers to create gap-filled activities with gamification elements; JMatch creates activities to match elements of two groups; JQuiz uses four types of tasks (Short answer; Multiple choice; Mixed; Alternative choice) and creates quiz; JCross creates crosswords; JMix mixes types of activities; The Masher allows to create units from the packages of the above types of exercises program automatically.

The article proves that Hot Potatoes program exercises diversify the routine implementation of typical exercises in electronic courses of LMS MOODLE, increase motivation of students to study and learn English for specific purpose, extend the term of interest etc. To make further research in this field we are going to study Qedoc, Xerte and


Серія: Педагогічні науки. - Вип.1. - Бердянськ : БДПУ, 2019. - 406 с.

iSpring programs and the role of created with their help gamification activities in formation of the communicative competence of future marine specialists, namely ship engineers.

Key words: gamification activities, LMS MOODLE, Hot Potatoes, ship engineers, communicative competence.

Вступ. Широке використання у наш час в освіті отримали новітні технології, серед яких особливо популярним $€$ інформаційно-освітнє електронне середовище навчального закладу, що дозволяє зібрати необхідні навчально-методичні матеріали в одному місці, забезпечує постійний доступ до них та до інтерактивних вправ тощо (Волошинов, 2018). Однією із проблем використання інформаційно-освітнього електронного середовища ми вбачаємо в лімітованій кількості інструментів, які забезпечують інтерактивні вправи та розміщення їх в електронному середовищі (Чернявський, 2013: 250).

До вітчизняних дослідників, які вивчали роль інформаційноосвітнього електронного середовища навчального закладу в підготовці студентів, відносимо таких: В. Бикова, Р.Гуревича, С.Григор'єва, I. Захарову, М. Козяра, С. Сисоєву, С. Панюкова, С. Позднякова, О. Кузнецова та ін. Вчені пропонували використовувати різні компоненти електронного середовища, одним із яких $€$ інтерактивні вправи. Вони стали предметом низки досліджень О. Пометун, Л. Пироженко, О. Комар, О. Ганик, О. Винницької-Юсипович, І Черешнюк, О. Нестеренко, В. Паращич та ін. Серед новітніх методик підвищення мотивації до навчання однією з найбільш ефективних $€$ гейміфікація, яка пропонує використовувати вправи, що перетворюють навчання у гру. Дослідженням гейміфікації як новітнього явища в навчанні займалися Б. Качан, О. Пасічник, В. Ярова, О. Ткаченко, А. Митєва, Д. Попов, Л. Сергеєва та ін. Однією із програм для створення гейміфікованих вправ $\epsilon$ Hot Potatoes, що стала предметом досліджень С. Богданова, O. Пивненко, L. Hughes, J. Stanford, I. Wild, S.P. Hillar, M. Cooch та ін.

Мета статті - окреслити роль та місце гейміфікованих вправ, створених за допомогою програми Hot Potatoes y формуванні комунікативної компетентності майбутніх суднових механіків.

Методи та методики дослідження. Задля досягнення окресленої мети нами був використаний комплекс взаємопов'язаних методів, а саме: метод термінологічного аналізу (задля тлумачення поняття "гейміфіковані вправи"), узагальнення даних, методологічні методи (компетентнісний підхід, системний підхід, діяльнісний підхід та гейміфікований підхід).

Результати та дискусії. Наведемо декілька тлумачень поняття "гейміфіковані вправи". У своїх дослідженнях багато сучасних науковців визначають гейміфіковані вправи (від англ. "game" - гра) як освітні у вигляді гри (наприклад: DuoLingo, Ribbon Hero, ClassDojo, GoalBook, The World Peace Game та ін.). Стосовно викладання іноземної мови дослідники тлумачать гейміфіковані вправи як такі, метою яких $\epsilon$ формування, вдосконалення та розвиток навичок і вмінь студентів у різних видах мовленнєвої діяльності шляхом багаторазового й 
різноманітного виконання мовленнєвих дій, які стають особистісно значущими для суб'єкта навчання, оскільки вмотивовані участю його в ігровій діяльності (Шерман, 2014: 191).

Програма Hot Potatoes дозволяє створювати гейміфіковані вправи та розміщувати в освітньо-комунікативному електронному середовищі ЗВО. До переваг цієї програми ми відносимо: простоту у використанні; різноманітність типів вправ; можливість використання декількох типів завдань у одній вправі; наявність звітів, які показують відповідь студента; оцінювання створених вправ платформою, на якій вони розташовані, та виставлення оцінок за виконання вправ у електронний журнал. Одна діяльність HotPot складається з необов'язкової сторінки входу, вправи електронного навчання та додаткової вихідної сторінки. Інтерактивна вебсторінка такого формату пропонує викладачам використовувати текстові, аудіо- та візуальні підказки та записувати їхні відповіді.

Для використання програми Hot Potatoes як діяльності освітньокомунікативного електронного середовища ЗВО адміністратор системи додає в модулі елемент курсу Hot Potatoes. Після цього в електронних курсах викладач має змогу додати діяльність Hot Potatoes, яку потрібно створити за допомогою однойменної програми на власному електронному пристрої. Для початку роботи з програмою потрібно обрати тип вправи із шести запропонованих: JClose, JMatch, JQuiz, JCross, JMix, The Masher (Рис.1).

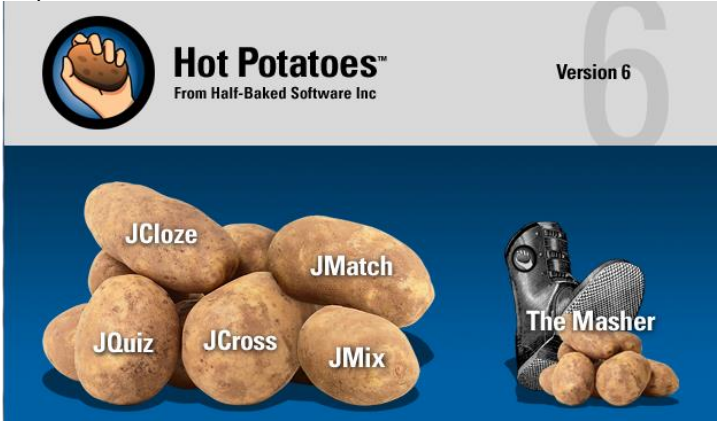

Рис. 1. Шість типів вправ програми Hot Potatoes

Вправа типу JCloze дозволяє створювати завдання із пропусками, які студент має заповнити словами/словосполученнями/частинами речення/реченнями/параграфами тексту. Кожен пропуск може мати підказку, створену викладачем: слово-синонім/антонім/дефініцію/приклад використання лексичної одиниці. Усі пропущені слова автоматично розміщуються після завдання. Текст завдання автоматично створюється програмою: Fill in all the gaps, then press "Check" to check your answers. Use the "Hint" button to get a free letter if an answer is giving you trouble. You can also click on the "[?]" button to get a clue. Note that you will lose points if you ask for hints or clues! (Заповніть усі пропуски, потім натисніть "Перевірити", щоб порівняти з вашою відповіддю. Використовуйте кнопку 
Серія: Педагогічні науки. - Вип.1. - Бердянськ : БДПУ, 2019. - 406 с.

"Підказка", щоб отримати випадкову літеру, якщо ви не знаєте відповіді. Ви також можете натиснути кнопку "[?]", щоб отримати підказку. Зверніть увагу, що ви втрачаєте поінти, якщо використаєте підказки!).

Вправу типу JCloze використовуємо для вивчення нових лексичних одиниць, перевірки вивченого лексичного та граматичного матеріалу тощо.

На рис. 2 можна побачити приклад використання цього типу вправи в освітньо-комунікативному електронному середовищі MOODLE (Modular Object-Oriented Dynamic Learning Environment) для вивчення англійської мови за професійним спрямуванням майбутніми судновими механіками (Дендеренко, 2015: 28).

Emergencies important for ship engineer

Gap-fill exercise

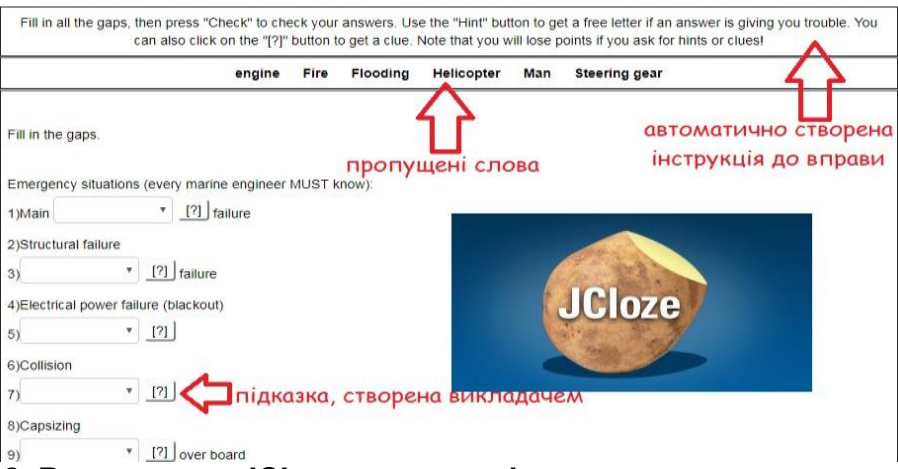

Рис. 2. Вправа типу JCloze для перевірки лексичних одиниць теми "Надзвичайні ситуації на морі" (Emergencies at sea)

Вправа типу JMatch дозволяє створювати завдання, де студент має порівняти дві групи елементів, які можуть мати формат тексту, відео або аудіо. Викладач пропонує підказку, яка буде відображатися при першому завантаженні елементів другого стовпчика. Усі елементи другого стовпчика перемішуються програмою автоматично. Викладач має змогу при створенні вправи перемістити елементи першого стовпчика та обрати пункт, який може бути використаним для прикладу. Програма автоматично створює завдання: Match the items on the right to the items on the left (Зіставте елементи правого стовпчика із елементами лівого стовпчика).

Вправу типу JMatch використовуємо для вивчення та перевірки нових лексичних одиниць, граматичного матеріалу, розвитку навичок читання тощо.

На авторських електронних курсах вивчення англійської мови для майбутніх суднових механіків використовуємо такі завдання цього типу вправ: порівняти слова/словосполучення та їх синоніми/антоніми/дефініції; параграфи тексту та їх заголовки; діалоги та їх закінчення/початки/ пропущені слова/словосполучення/фррази; питання та відповіді. 
Рис. 3 показує приклад використання цього типу вправи на платформі MOODLE для вивчення англійської мови за професійним спрямуванням (тема "Надзвичайні ситуації у машинному відділенні").

Engine Room emergencies o

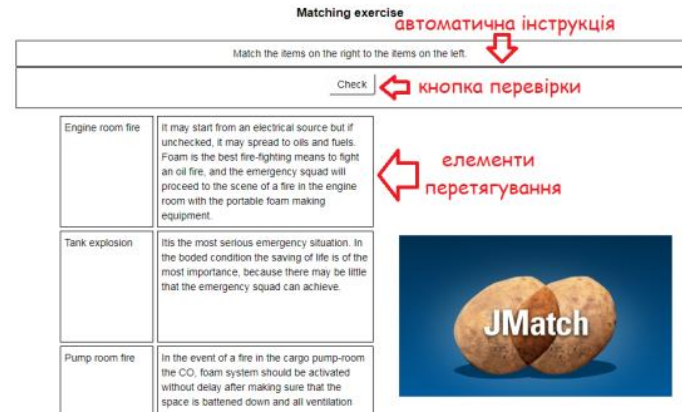

\section{Рис. 3. Приклад вправи типу JMatch на платформі MOODLE електронного курсу "Англійська мова за професійним спрямуванням"}

Вправа типу JQuiz (Вікторина) дозволяє створити вікторину 3 необмеженою кількістю питань чотирьох типів: альтернативний вибір, коротка відповідь, змішаний, множинний вибір. Альтернативний вибір дозволяє обрати правильну відповідь із декількох варіантів, множинний (рис. 4) - кілька правильних відповідей. Коротка відповідь дозволяє написати відповідь одним або декількома словами. Змішаний тип питання поєднує типи питань із відповіддю відкритого типу та множинний вибір: після неправильної відповіді (викладач визначає кількість неправильних відповідей) питання типу "коротка відповідь" трансформується в питання типу "множинний вибір". Програма автоматично формує текстове повідомлення після відповіді на кожне питання: студент бачить свій прогрес у відсотках та у цифрах (1/4). Firefighting quiz $*$

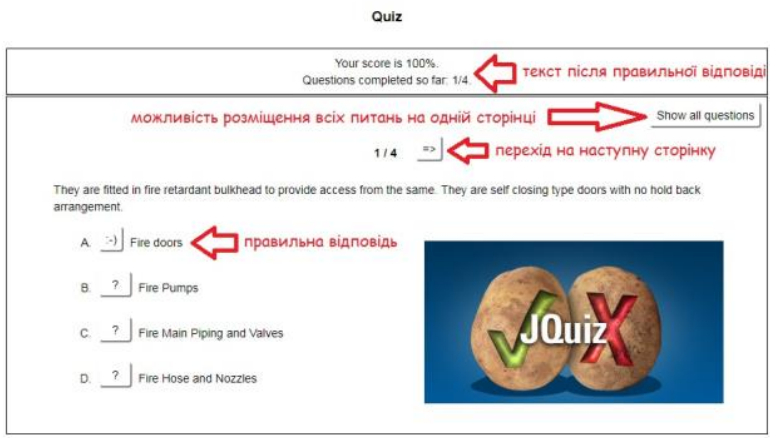

Рис. 4. Приклад питання типу JQuiz (Множинний вибір) теми "Firefighting" (Пожежогасіння) 
Вправа типу JCross дозволяє створити кросворд, завдання якого полягає у вписуванні літер у перехресні рядки клітинок накресленої фігури так, щоб за горизонталлю та вертикаллю вийшли загадані слова.

Вправа типу The Masher дозволяє автоматично створити юніти 3 пакетів вищеперерахованих типів вправ програми.

До елементів гейміфрікації вищезазначених вправ ми відносимо: поінти, можливість використання підказок, візуальний прогрес, право на помилку, можливість розпочати гру знову, ігровий дизайн (наявність кнопок "[?]", "???", ":-)", ":-(", "?", "=>").

Висновки. Новітні технології в освіті диктують свої вимоги до професійної підготовки сучасного морського фахівця, де використання освітньо-комунікативного електронного середовища закладу $є$ на часі. Вправи, створені за допомогою програми Hot Potatoes, урізноманітнюють рутинне виконання типових вправ у освітньо-комунікативному електронному середовищі, підвищують мотивацію майбутніх фахівців, подовжують термін зацікавленості у вирішенні проблеми та збільшують ймовірність досягнення мети. На електронних курсах вивчення англійської мови вправи програми Hot Potatoes сприяють фоомуванню комунікативної компетентності студентів.

Перспективи подальших пошуків у напрямі дослідження вбачаємо у дослідженні програм Qedoc, Xerte та iSpring для створення гейміфікованих вправ та розміщення їх на електронних курсах для формування комунікативної компетентності майбутніх суднових механіків. Саме діяльність Hot Potatoes може обробляти вправи, створені за допомогою вищеперерахованих програм.

\section{Література}

1.Волошинов С. А. Реалізація компетентнісного підходу у ступеневій підготовці морських фахівців / С.А.Волошинов //Ukrainian Journal of Educational Studies and Information Technology. - 2018. - Том 6, №1 - C. 49-55.

2.Дендеренко О. О. Шляхи формування професійної компетентності суднового механіка при вивченні інтегрованого курсу гідромеханіки у морському коледжі / О. О. Дендеренко // Збірник наукових праць Кам'янець-Подільского національного університету імені Івана Огієнка. Серія педагогічна. - 2015. - № 21. - C. 27-30.

3.Чернявський В. В. Стандартизація підготовки фрахівців морської галузі на засадах компетентнісного підходу / В. В. Чернявський // Збірник наукових праць Кам'янець-Подільського національного університету ім. Івана Огієнка. Сер. : Педагогічна. - 2013. - Вип. 19. - С. 250- 253

4.Шерман М.І. Інформаційна культура майбутніх інженерів-судноводіїв як психолого-педагогічний феномен/ М.І.Шерман, О.М. Безбах //Актуальні проблеми державного управління, педагогіки та психології : зб. наук. праць ХНТУ. - Вип.1 (10). - Херсон, 2014. - С. 190-193.

\section{References}

1. Voloshynov, S. A. (2018). Reallzatslya kompetentnlsnogo pldhodu u stupenevly pldgotovtsl morskih fahlvtslv [Realization of a competent approach in the stage training of marine specialists], Ukrainian Journal of Educational Studies and Information Technology. 6 (1), $49-50$ [in Ukrainian].

2. Denderenko, O. O. (2015). Shliakhy formuvannia profesiinoi kompetentnosti 